\title{
SIKAP BAHASA DAN KEMAMPUAN MEMAHAMI BACAAN BAHASA INGGRIS MAHASISWA: STUDI KASUS DI FIB UNPAD
}

\author{
Ida Farida Sachmadi, Lestari Manggong, dan Lia Maulia Indrayani \\ Program Studi Sastra Inggris, Fakultas Ilmu Budaya, Universitas Padjadjaran, Bandung \\ E-mail: i.farida@unpad.ac.id
}

\begin{abstract}
ABSTRAK. Telah dilakukan penelitian kepada 144 mahasiswa strata S1 dari Fakultas Ilmu Budaya mengenai sikap bahasa mereka terhadap Bahasa Inggris. Survey ini bertujuan untuk menilai sikap mahasiswa terhadap Bahasa Inggris, model pembelajaran Bahasa Inggris, dan materi serta keterampilan berbahasa Inggris. Metode penelitian yang digunakan adalah teori sikap bahasa yang diambil dari Sarnoff dan Asmah, dan angket yang menggunakan Skala Likert. Penelitian ini juga bermaksud mengukur kemampuan mahasiswamahasiswa ini dalam keterampilan memahami bacaan Bahasa Inggris melalui lima komponen keterampilan: (1) kosa-kata yang dimiliki, (2) menginferensi, (3) mengenali kata acuan, (4) menemukan gagasan utama, dan (5) mencari informasi pendukung, berdasarkan uraian dari Kintsch dan Grabe. Pesertanya adalah mahasiswa semester tiga: 39 mahasiswa dari Prodi Sastra Jepang, 52 dari Sastra Sunda, dan 53 dari Ilmu Sejarah. Data diperoleh dari tes kemampuan memahami bacaan. Hasil dari penelitian ini menunjukkan adanya perbedaan yang jelas pada level kemampuan membaca mahasiswa dari tiga prodi ini, walau mereka telah mendapatkan pembelajaran Bahasa Inggris yang sama selama satu semester. Mahasiswa-mahasiswa di satu prodi menunjukkan kemampuan yang tinggi dalam memahami bacaan dan siap membaca buku teks dan jurnal dalam Bahasa Inggris; prodi lain dapat mulai diajarkan membaca teks dengan level tinggi, namun satu prodi lainnya terlihat belum mampu menerima teks Bahasa Inggris untuk level universitas. Sementara itu, hasil dari survey angket menunjukkan perbedaan kecil pada mahasiswa-mahasiswa ini dalam memandang pembelajaran Bahasa Inggris; dan hasil ini juga dapat dijadikan dasar untuk menyusun model pembelajaran yang tepat sesuai harapan mahasiswa yang akan mendukung perkuliahan mereka di bidang ilmu masing-masing.
\end{abstract}

Kata kunci: sikap bahasa; level kemampuan membaca; mahasiswa FIB Unpad.

\section{LANGUAGE ATTITUDES AND READING PROFICIENCY IN ENGLISH : A CASE STUDY OF STUDENTS IN FIB UNPAD}

\begin{abstract}
Universitas Padjadjaran students, especially from Faculty of Cultural Sciences, are surveyed to find their attitudes towards English. This survey aims to asses the sudent's attitude towards English, learning model, and the materials and skills in English. The method of this research is based upon the language attitudes theory, adopted from Sarnoff and Asmah, and a series of questionaire based on Likert Scale. This study also measures reading proficiency levels of these students using five-component skills involving measures of (1) vocabulary knowledge, (2) drawing inference, (3) idetifying references, (4) identifying the main idea, and (5) identifying supporting information, based on Kintsch and Grabe. The participants are second year undergraduates: 39 from Japanese Study Progam, 52 from Sundanese, and 53 from History Study Program. The data are collected through a reading comprehension test. The results of this study indicate that there is a clear difference from the students reading competency levels in these three study programs, even when students have joined the same English course for one semester. Students of one study program has high reading proficiency level and ready to read text books and journals; the other could be prepared to learn advanced English, but there is one study program which is inadequately prepared for university reading. Meanwhile, the result of the survey shows a slight difference of these students in perceiving English learning; then, it could be used to create an appropriate learning model for their further study in their field of science respectively.
\end{abstract}

Key words: language attitudes; reading proficiency level; students of FIB Unpad.

\section{PENDAHULUAN}

Pada tahun ajaran 2016/2017, Universitas Padjadjaran mengadakan program Tahap Persiapan Bersama (HITS-Happiness and Integration for Successful Transition Studies) selama satu semester untuk memberikan mata kuliah wajib pada mahasiswa baru. Mata kuliah Bahasa dijadikan satu, yakni Bahasa Indonesia dan Bahasa Inggris, namun karena materi yang disampaikan berbeda - Bahasa Indonesia lebih menekankan keterampilan menulis teks ilmiah, sedangkan Bahasa Inggris menekankan keterampilan membaca teks umum, pelaksanaan pembelajaran kedua bahasa ini dibedakan. Karena itu, materi masing-masing bahasa dapat disampaikan pada mahasiswa selama setengah semester ( 7 pertemuan).
Mata kuliah lain pun demikian, seperti Agama, Pancasila, dan Kewarganegaraan. Untuk Olah-Raga, Kesenian, dan Kreativitas (OKK) dilaksanakan di dalam ruang kelas dan terjun ke lapangan membuat program untuk penduduk setempat.

Untuk Bahasa Inggris, materi ditekankan pada keterampilan membaca dengan pertimbangan mahasiswa membutuhkan keterampilan ini saat mereka mulai mempelajari bidang ilmu masing-masing dengan menambah pengetahuan dari sumber teks yang berbahasa Inggris, baik dari buku teks ataupun jurnal internasional yang tercetak dan digital. Mortimer J. Adler dan Charles Van Doren pada tahun 1940-an menulis buku yang berjudul How to Read a Book, dan menyebutkan bahwa 'reading is tools', yang kemudian membawa masyarakat Eropa 
masuk ke budaya membaca (literate) (Rohman, 2016: 255). Dalam penelitian tentang kemampuan mahasiswa dalam membaca buku teks, Prijana dan Asep Saiful Rohman menemukan bahwa tidak ada hubungan yang signifikan antara mahasiswa ber-IPK tinggi dengan cepat tidaknya mereka membaca; namun, simpulan yang diperoleh dari penelitian mereka adalah bahwa mahasiswa ber-IPK tinggi lebih terampil membaca sehingga mereka dapat membaca lebih cepat dan memeroleh informasi lebih banyak: "[...] yang menentukan waktu baca lebih cepat [adalah] disebabkan oleh faktor keterampilan dan keterlatihan. Semakin terampil membaca, semakin singkat waktu bacanya."(Rohman, 2016: 259-260). Karena itu, mahasiswa harus diajarkan dan dilatih keterampilan membaca, termasuk bacaan (terutama buku teks dan jurnal) dalam Bahasa Inggris, yang jauh lebih banyak tersedia di media digital.

Pada penelitian ini, telah dievaluasi pembelajaran program HITS 2016 dengan memeriksa kemampuan mahasiswa semester tiga dalam memahami teks berbahasa Inggris dari tiga program studi di Fakultas Ilmu Budaya, yaitu dari prodi bahasa asing (dipilih Prodi Sastra Jepang), prodi bahasa non-asing (Prodi Sastra Sunda), dan prodi non-bahasa (Prodi Ilmu Sejarah). Mereka diberi tes keterampilan membaca, diambil dari teks level upper-intermediate, yang sering muncul dalam TOEFL. Tes ini mencakup uji keterampilan finding topics, getting main ideas, scanning/finding stated information, guessing vocabulary, dan making inference. Kemudian, telah diteliti juga sikap mereka terhadap pembelajaran Bahasa Inggris yang telah mereka dapatkan pada tahun ajaran sebelumnya, yaitu 2016/2017, serta kebutuhan mereka terhadap Bahasa Inggris untuk menunjang perkuliahan mereka di bidang ilmu masing-masing.

Hasil yang dapat diberikan dari penelitian ini adalah gambaran yang tepat mengenai kemampuan mahasiswa FIB setelah belajar bahasa Inggris selama satu semester, juga mengenai sikap mereka terhadap pembelajaran Bahasa Inggris, dan rekomendasinya. Tujuan diadakannya penelitian ini adalah untuk mengukur kemampuan mahasiswa dalam memahami teks bahasa Inggris untuk mengetahui tingkat pemahaman mereka dan untuk mengetahui sikap mereka terhadap pembelajaran Bahasa Inggris yang telah mereka dapatkan pada tahun sebelumnya. Untuk mencapai tujuan ini, jenis riset deskriptif telah digunakan. Lebih lanjut lagi, hasil penelitian ini dapat dijadikan dasar untuk menyusun model pembelajaran yang sesuai untuk mahasiswa dalam Program Studi yang berbeda-beda, sehingga kemudian dapat digunakan oleh dosen pengampu bahasa Inggris di Fakultas Ilmu Budaya.

Penelitian terhadap kemampuan membaca teks Bahasa Inggris mahasiswa di sebuah kampus telah dilakukan oleh peneliti-peneliti Indonesia. Veronika Unun Pratiwi dkk (2015) telah mengadakan penelitian atas peningkatan kemampuan membaca teks Bahasa Inggris pada mahasiswa di luar Program Studi Bahasa Inggris di Universias Veteran Bangun Nusantara di Sukoharjo, Jawa Tengah. Para peneliti mengamati adanya peningkatan kemampuan memahami teks dari mahasiswa setelah diberi interferensi pembelajaran mengenal kosa-kata dan struktur kalimat yang sulit (Pratiwi, 2015). Selain itu, peneliti lain, Muflihah (2016), juga melakukan penelitian kemampuan membaca teks Bahasa nggris pada mahasiswa kelas bilingual di IAIN Purwokerto, Jawa Tengah, dan hasilnya menunjukkan kemampuan membaca yang rendah karena rerata nilai kemampuan membaca mereka adalah 37 dari total nilai 67 (Muflihah, 2016). Peneliti lainnya, Alvii TB Siregar dan Evangeline H. (2017) juga melakukan penelitian atas kemampuan berbahasa Inggris pada mahasiswa Prodi Ilmu Keperawatan di STIKES Jenderal Achmad Yani, Cimahi, Jawa Barat. Mereka menemukan bahwa kemampuan mahasiswa masih rendah dengan rerata nilai tes 387 dari standar 535 dengan menggunakan tes yang berstandar internasional (Siregar, 2017).

Sikap bahasa mahasiswa terhadap bahasa Inggris juga telah diteliti di berbagai kampus. Indra Kusuma dan Surya Adnyani (2016) meneliti sikap bahasa mahasiswa Jurusan Pendidikan Bahasa Inggris di Universitas Pendidikan Singaraja dan juga orang-tua mereka dengan memberikan kuesioner dari Gardner. Hasilnya adalah ketertarikan mahasiswa dan orang-tua yang sangat tinggi terhadap bahasa Inggris (Kusuma, 2016). Sebelumnya, Dewa Komang Tantra dkk (2014) juga meneliti motivasi dan sikap bahasa mahasiswa di universitas yang sama namun pada tahun yang berbeda. Tantra menemukan bahwa motivasi memberi pengaruh pada prestasi belajar mahasiswa di kelas sebesar 6,3\% dan sikap bahasa berpengaruh 11,2\% (Tantra, 2014). Lestari Manggong (2017) meneliti sikap bahasa mahasiswa di luar Prodi Bahasa Inggris terhadap metode pembelajaran yang diberikan diUniversitasPadjadjaran KampusPangandaran. Hasilnya menunjukkan bahwa mahasiswa menyenangi metode belajar yang berfokus pada mahasiswa dan lebih menyukai belajar berbicara daripada menulis (Manggong, 2017).

Selain sikap terhadap bahasa Inggris dan metode pembelajarannya, peneliti Indonesia juga meneliti sikap bahasa mahasiswa terhadap variasi bahasa Inggris, seperti yang dilakukan Hepi Adityarini dkk (2009) pada mahasiswa Prodi Bahasa Inggris Universitas Muhammadiyah Surakarta. Mereka menemukan bahwa sikap mahasiswa terhadap tiga variasi bahasa, yaitu General American, British English, dan Indonesia English, terutama pada kecepaan dan pengucapan dalam berbicara, mahasiswa-mahasiswa ini berpendapat bahwa (1) versi Indonesia English lebih mudah diikuti dan paling jelas pengucapannya; (2) versi American English dianggap paling menarik penyampaiannya; dan (3) versi British English adalah yang paling sulit diikuti (Adtyarini, 2009). Alvii TB Siregar (2016) selain meneliti kemampuan berbahasa Inggris mahasiswa non-prodi Bahasa Inggris 
di STIKES Cimahi, juga meneliti sikap mereka terhadap bahasa ini. Hasil yang didapatkan adalah bahwa mahsiswa memiliki kemampuan yang rendah dalam berbahasa Inggris, tapi memiliki motivasi yang tinggi dan sikap yang mendukung terhadap pembelajaran Bahasa Inggris (Siregar, 2017).

Penelitian yang dilakukan oleh penulis hampir sama dengan yang dilakukan oleh Siregar (2017), yaitu meneliti kemampuan mahasiswa dalam menggunakan bahasa Inggris dan sikap mereka terhadap bahasa tersebut. Dengan diadakannya penelitian ini, diharapkan dapat menambah informasi mengenai kemampuan mahasiswa di kampus-kampus di Indonesia dalam berbahasa Inggris, sehingga dapat menjadi masukan untuk target capaian pembelajaran mata kuliah Bahasa Inggris dan metode pembelajarannya untuk kampus lain.

\section{METODE}

Riset ini dilakukan pada mahasiswa yang masuk Unpad pada tahun ajaran 2016/2017 di tiga prodi Fakultas Ilmu Budaya Universitas Padjadjaran, yang berarti pada tahun ini mereka sedang berada di semester ketiga. Tahap pertama adalah mencari tahu kemampuan mahasiswa dalam memahami teks berbahasa Inggris. Cara mengetahuinya adalah memberikan tes pada mahasiswamahasiswa tersebut. Pertanyaan yang diberikan adalah yang dapat menggali kemampuan mereka dalam mendapatkan topik dan gagasan utama, informasi spesifik, makna kosa kata, dan pengambilaan informasi dari inferensi. Tahap berikutnya, hasil data akan dianalisis sehingga diketahui jenis pertanyaan mana yang sulit. Kemudian, dicari juga metode pembelajaran yang diinginkan mahasiswa fakultas ilmu budaya ini dengan cara survey melalui angket. Dari penyebaran angket di tiga prodi tersebut di atas, akan dapat dianalisis keterampilan bahasa, materi, dan metode seperti apa yang disenangi mahasiswa. Selain evaluasi pembelajaran tahun sebelumnya, diteliti juga sikap mereka terhadap keinginan dan kebutuhan mereka untuk melajutkan belajar Bahasa Inggris. Hasil kedua kegiatan ini dapat menjadi dasar pembuatan model pembelajaran dan buku ajar yang dapat ditawakan pada prodi-prodi di FIB untuk diberikan pada mata kuliah lanjutan bila dibutuhkan.

Tim peneliti telah mengukur tingkat pemahaman membaca teks bahasa Inggris mahasiswa melalui analisis tingkat kesukaran dari tes yang diberikan. Penyusunan pertanyaan dalam tes difokuskan pada lima komponen kemahiran, yaitu: (1) vocabulary knowledge, (2) drawing inferences, (3) references, (4) identifying the main ideas, dan (5) identifying supporting information. Untuk menguji kemampuan mereka dalam memahmai bacaan Bahasa Inggris, telah diberikan satu tes dalam keterampilan ini. Total jumlah soal yang dikerjakan dalam tes adalah 12 soal, dengan pembagian 6 soal untuk Teks 1 dan 6 soal untuk Teks 2. Sebarannya dalam masing-masing teks soal adalah sebagai berikut: dua pertanyaan mengenai supporting information, satu pertanyaan main ideas, satu pertanyaan vocabulary, satu pertanyaan references, dan satu pertanyan inference.

Penyusunan lima komponen kemahiran ini didasarkan pada salah satu model pemahaman bacaan (reading comprehension) teks Bahasa Inggris, yakni model Konstruksi-Integrasi (Construction-Integration (CI) model), yang dianggap model yang paling baru dan valid. Menurut Kintsch, model CI membedakan dua model membaca: model teks pemahaman pembaca dan model situasi dari penafsiran pembaca. Menurut model teks, memahami bacaan terletak pada dua level: lokal dan global. Contoh level lokal mencakup pengetahuan tentang kata benda, kata kerja, dan modifier, yang membangun pemahaman kalimat; sedangkan, di level global, membaca menggunakan pengetahuan bahasa dan hubungan antar kalimat untuk dapat memahami isi teks, misalnya teknik inferensi. Dalam memahami bacaan, diperlukan juga model situasi dari penafsiran pembaca. Di model ini, pembaca menggunakan pengetahuan yang telah dimiliki dalam rangka memahami teks yang sedang dibaca, dengan cara mencari informasi eksplisit dan implisit, selain membangun penafsiran bebas pembaca (Dijk, 1978; Kintsch, 1998). Penafsiran bebas dapat dipengaruhi oleh maksud pembaca, tujuan membaca, genre teks, dan penilaian informasi penting dalam teks (Grabe, 2011). Teknik ini termasuk keterampilan membaca tingkat tinggi, sedangkan pemahaman dari mengetahui makna kata, frasa, dan formasi struktur kalimat termasuk keterampilan membaca tingkat rendah, dan kedua teknik ini menurut Kintsch dibutuhkan dalam memahami bacaan (Kintsch, 1998). Dalam penelitian ini, lima keterampilan yang akan diteliti dari dua model ini, seperti telah disebut di atas.

Definisi mengenai sikap bahasa diambil dari Sarnoff (1970), yang menjelaskan bahwa sikap bahasa adalah "disposition to react favourably and unfavourably to a class of objects"; dan Asmah (1990) mendefinisikan konsep sebagai "the way an individual feels ad thinks about something or someone" (Sarnoff dan Asmah dalam Aziz, 1994: 87). M. Sallehudin Abd. Aziz, yang meneliti sikap bahasa mahasiswa Universitas Kuala Lumpur (UKM) terhadap Bahasa Inggris, menuliskan bahwa dalam meneliti sikap, kita harus juga mempertimbangkan unsur penting lain, yaitu motivasi. Ia mengutip penjelasan Gardner yang menunjukkan adanya hubungan antara sikap dan motivasi. Azis mengatakan bahwa menurut Gardner motivasi adalah kombinasi dari usaha dan kemauan untuk mencapai tujuan pembelajaran bahasa dan sikap baik terhadap pembelajaran itu (Aziz, 1994: 87). Pada penelitian ini, akan terlihat juga motivasi mahasiswa tida prodi yang diteliti terhadap pembelajaran Bahasa Inggris.

Penyusunan angket didasarkan pada Skala Likert, yang menemukan metode untuk mengukur karakteristik dan sifat-sifat kepribadian seseorang. Skala pengukuran sikap ini terdiri atas pertanyaan-pertanyaan dengan lima 
alternatif jawaban, yaitu (1) STS : Sangat Tidak Setuju, (2) TS : Tidak Setuju, (3) R : Ragu-ragu, (4) S : Setuju, dan (5) SS : Sangat Setuju (Boone, 2012). Angket yang diberikan terdiri dari empat tema: (1) Mengenai efektifitas perkuliahan Bahasa Inggris tahun ajaran 2016/2017, (2) Model perkuliahan Bahasa Inggris, (3) Kebutuhan konten dan keterampilan Bahasa Inggris, (4) Perkuliahan Bahasa Inggris lanjutan.

Angket yang sudah diisi dianalisis dengan cara menghitung jumlah pemilih masing-masing pernyataan, dan membandingkan jumlah yang Setuju dan Sangat Setuju (S + SS) dengan jumlah pemilih yang Sangat Tidak Setuju dan Tidak Setuju (STS+TS). Dari perbandingan tersebut, akan didapatkan kecenderungan masing-masing prodi dalam memandang 4 tema tersebut di atas. Tafsiran persentase pilihan jawaban diuraikan dalam tabel berikut

Tabel 1. Tafsiran Persentase Pilihan Jawaban (Wiji, 2014)

\begin{tabular}{ll}
\hline \multicolumn{1}{c}{ Rentang } & \multicolumn{1}{c}{ Tafsiran } \\
\hline 0 & Tidak ada \\
$1-25$ & Sedikit \\
$26-49$ & Hampir setengahnya \\
50 & Setengahnya \\
$51-75$ & Sebagian besar \\
$76-99$ & Hampir seluruhnya \\
100 & Seluruhnya \\
\hline
\end{tabular}

Setiap poin pernyataan akan ditafsirkan berdasarkan ukuran dalam tabel di atas. Kemudian dari total jawaban, akan didapatkan penilaian atau evaluasi pembelajaran Bahasa Inggris dalam program HITS 2016/2017, dan model pembelajaran Bahasa Inggris yang diharapkan mahasiswa. Berikut ini akan diuraikan satu per satu hasil analisis dari tes dan angket yang telah diberikan.

\section{HASIL DAN PEMBAHASAN}

\section{Kemampuan Memahami Bacaan Bahasa Inggris Mahasiswa}

Terdapat 39 mahasiswa Prodi Sastra Jepang, 53 dari Sastra Sunda, dan 52 dari Ilmu Sejarah yang megikuti tes ini. Penghitungan jawaban benar dari hasil tes diuraikan dalam tabel di bawah ini

Tabel 2. Presentase Jumlah Jawaban Benar

\begin{tabular}{lccc}
\multirow{2}{*}{\multicolumn{1}{c}{ Jenis Pertanyaan }} & \multicolumn{3}{c}{ Persentase Jawaban Benar } \\
\cline { 2 - 4 } & Sastra & Ilmu & Sastra \\
& Jepang & Sejarah & Sunda \\
supporting information & $88 \%$ & $86 \%$ & $79 \%$ \\
main ideas & $87 \%$ & $61 \%$ & $41 \%$ \\
references & $86 \%$ & $67 \%$ & $53 \%$ \\
vocabulary & $86 \%$ & $44 \%$ & $54 \%$ \\
inference & $78 \%$ & $70 \%$ & $45 \%$ \\
\hline
\end{tabular}

Dari data tersebut, terlihat bahwa kecenderungan di Prodi Sastra Jepang adalah: jenis pertanyaan yang paling mudah bagi mahasiswa Prodi Sastra Jepang adalah pertanyaan supporting information, dengan rata- rata jumlah jawaban benar adalah 34,4 orang dari 39 mahasiswa (88\%). Sedangkan, pertanyaan yang paling sulit bagi mereka adalah jenis pertanyaan inference, dengan rata-rata jumlah jawaban benar 30,5 orang (78\%).

Dari data itu juga, terlihat bahwa kecenderungan pada mahasiswa Prodi Ilmu Sejarah adalah: kemampuan tertinggi mahasiswa adalah dalam hal menjawab jenis pertanyaan supporting information, dengan jumlah benar rata- rata 45,5 orang dari 52 (86\%). Sebaliknya, kemampuan terrendah mahasiswa adalah dalam hal menjawab jenis pertanyaan vocabulary, dengan jumlah benar rata-rata 23,5 dari 52 (44\%).

Dari data itujuga, dapat dilihat bahwa kecenderungan mahasiswa di Prodi Sastra Sunda adalah: kemampuan tertinggi mahasiswa adalah dalam hal menjawab jenis pertanyaan supporting information, dengan rata-rata jumlah jawaban benar adalah 41 orang (79\%). Sebaliknya, kemampuan terrendah mahasiswa adalah dalam hal menjawab jenis pertanyaan main ideas, dengan jumlah rata-rata jawaban benar adalah 22 orang (41\%)

Tabel di atas menunjukkan perbedaan yang cukup tajam antara kemampuan mahasiswa Prodi Sastra Jepang dan Sastra Sunda, sedangkan Prodi Ilmu Sejarah berada di tengahnya. Di atas 80\% dari mahasiswa Prodi Sastra Jepang mampu menjawab pertanyaan dengan benar kecuali jenis pertanyaan inference. Sedangkan di Prodi Ilmu Sejarah, lebih dari $60 \%$ dapat menjawab pertanyaan dengan benar untuk semua jenis pertanyaan kecuali pertanyaan tentang makna kosa kata sesuai konteks (vocabulary). Namun, hanya jenis pertanyaan supporting information secara eksplisit yang dapat dijawab lebih dari 60\% mahasiswa Prodi Sastra Sunda, empat jenis lainnya dijawab dengan benar oleh kurang dari 50\% mahasiswa, dengan jenis pertanyaan pencarian gagasan utama (main ideas) yang paling sedikit dijawab benar.

Bila melihat persentase jumlah mahasiswa yang menjawab betul di atas $60 \%$ (nilai tes di atas 60 ), urutannya adalah: Sastra Jepang 92\%, Ilmu Sejarah 64\%, dan Sastra Sunda hanya 39\% dari jumlah total mahasiswa masingmasing kelas yang mengikuti tes ini. Diteliti juga tingkat kesukaran soal bagi masing-masing prodi. Secara umum, dapat terlihat bahwa persentase kesulitan tiap jenis soal adalah sebagai berikut

\section{Tabel 3. Tingkat Kesukaran Soal}

\begin{tabular}{lccc}
\hline \multirow{2}{*}{ Jenis Pertanyaan } & Persentase & & \\
\cline { 2 - 4 } inference & Sastra Jepang & Ilmu Sejarah & Sastra Sunda \\
references & $22 \%$ & $56 \%$ & $59 \%$ \\
vocabulary & $14 \%$ & $39 \%$ & $55 \%$ \\
main ideas & $14 \%$ & $33 \%$ & $47 \%$ \\
supp o r t ing & $13 \%$ & $30 \%$ & $46 \%$ \\
information & $12 \%$ & $14 \%$ & $21 \%$ \\
\hline
\end{tabular}

Dari tabel ini dapat disimpulkan bahwa kemampuan mahasiswa Program Studi Sastra Jepang masih rendah dalam menginferensi atau memeroleh informasi implisit 
(inference). Sementara itu, dari data tersebut terlihat bahwa mereka dapat dengan mudah mendapatkan informasi eksplisit dalam teks.

Tabel di atas juga ini menunjukkan bahwa kemampuan mahasiswa Program Studi Ilmu Sejarah dalam hal mengetahui makna kata atau memahami kosa kata berdasarkan konteks, masih rendah. Sementara itu, dari data tersebut terlihat bahwa mahasiswa Program Studi Ilmu Sejarah unggul dalam hal memahami informasi yang tercantum dalam teks.

Dapat diketahui juga bahwa mahasiswa Sastra Sunda mengalami kesulitan dalam menemukan gagasan utama (main ideas) dalam sebuah teks, lebih sulit daripada menemukan gagasan tersembunyi/implisit dalam teks, yang biasanya terlihat dari jenis pertanyaan inference. Sebagian mahasiswa mempunyai kemampuan yang rendah dalam mengetahui makna kosa kata sesuai konteks, seperti terlihat dari jenis pertanyaan vocabulary dan references. Sedangkan, dalam memeroleh informasi pendukung (supporting information), hampir semua mahasiswa Sastra Sunda yang diberi tes ini mampu menyelesaikannya.

\section{Sikap Bahasa Mahasiswa}

Terdapat empat poin pertanyaan dalam survey; berikut diuraikan satu-persatu hasilnya.

A. Efektifitas Perkuliahan Bahasa Inggris Tahun Ajaran 2016/2017.

Mengenai hal ini, hasil survey dapat dilihat pada tabel 4. Dari tabel 4 diperoleh data bahwa hampir semua mahasiswa Prodi Sastra Jepang senang belajar Bahasa Inggris dan bukan hanya untuk mendapatkan nilai bagus, serta setengahnya memprioritaskan pembelajaran Bahasa Inggris. Begitu pula dengan mahasiswa Prodi Sastra Sunda dan Ilmu Sejarah, mereka senang belajar bahasa ini namun sebagian besar tidak mendahulukannya dari mata kuliah lain. Kemudian, hampir setengah dari mahasiswa Sastra Jepang berpendapat dapat memahami konsep Bahasa Inggris yang sulit, dan sebagian besar merasa mampu mengerjakan tes-tes Bahasa Inggris dengan baik. Berkebalikan dengan mahasiswa Sastra Sunda, sebagian besar dari mereka merasa tidak mampu memahami konsep yang sulit dan mereka juga tidak yakin apakah dapat mengerjakan tes-tesnya dengan baik. Sedikit berbeda dengan mahasiswa Ilmu Sejarah, hampir setengahnya merasa ragu apakah dapat memahami konsep Bahasa Inggris yang sulit dan sebagaian besar berpendapat bahwa mereka tidak mampu mengerjakan tes-tesnya dengan baik.

Tentang pembelajaran Bahasa Inggris yang mereka peroleh di semester satu pada tahun ajaran 2016/2017, sebagian besar mahasiswa Sastra Jepang berpartisipasi dalam perkuliahan Bahasa Inggris saat kontennya menarik dan senantiasa berubah, tapi hampir setengahnya ragu apakah perkuliahannya menantang; berbeda dengan dua prodi lainnya: hampir semua mahasiswa Sastra Sunda dan sebagian besar mahasiswa Ilmu Sejarah menganggap perkuliahan Bahasa Inggris pada program HITS cukup menantang. Mahasiswa Sastra Jepang terlihat sudah menguasai konsep-konsep Bahasa Inggris yang diberikan di perkuliahan sehingga merasa tidak tertantang mempelajarinya.

Mengenai metode pembelajaran perkuliahan mereka dalam mata kuliah Bahasa Inggris, sebagian besar mahasiswa di tiga prodi ini merasa tidak yakin apakah sudah menjadi peserta yang aktif dikelas. Hampir setengah dari mahasiswa Sastra Jepang ragu apakah dapat memahami pelajaran karena menggunakan peralatan audiovisual, sedangkan mahasiswa Sastra Sunda dan Ilmu Sejarah berpendapat mereka dapat memahami pelajaran dengan bantuan teknologi tersebut.

\section{Tabel 4. Efektifitas Perkuliahan}

\begin{tabular}{|c|c|c|c|c|}
\hline \multirow{2}{*}{ No } & \multirow{2}{*}{ Pernyataan } & \multicolumn{3}{|c|}{ Jawaban } \\
\hline & & \multicolumn{3}{|c|}{ Sangat Setuju \& Setuju } \\
\hline & Efektifitas Perkuliahan Bahasa Inggris tahun ajaran 2016/2017 & Sastra Jepang & Ilmu Sejarah & Sastra Sunda \\
\hline 1 & Saya senang belajar Bahasa Inggris & $85 \%$ & $89 \%$ & $81 \%$ \\
\hline 2 & Saya belajar Bahasa Ing-gris hanya untuk mendapatkan nilai bagus & $8 \%$ & $11 \%$ & $6 \%$ \\
\hline 3 & Saya dapat memahami konsep Bahasa Inggris yang sulit & $44 \%$ & $15 \%$ & $12 \%$ \\
\hline 4 & Saya dapat mengerjakan tes-tes Bahasa Inggris dengan baik & $69 \%$ & $28 \%$ & $23 \%$ \\
\hline 5 & $\begin{array}{l}\text { Saya bersedia untuk berparti sipasi dalam perkuliahan Bahasa Ing- } \\
\text { gris apabila kontennya menarik dan senantiasa berubah }\end{array}$ & $77 \%$ & $92 \%$ & $81 \%$ \\
\hline 6 & Saya adalah peserta aktif di kelas bahasa Inggris & $31 \%$ & $40 \%$ & $21 \%$ \\
\hline 7 & $\begin{array}{l}\text { Saya dapat memahami konsep Bahasa Inggris dengan jelas karena } \\
\text { dalam perkuliahan menggunakan peralatan au-dio visual yang } \\
\text { memadai }\end{array}$ & $28 \%$ & $43 \%$ & $42 \%$ \\
\hline 8 & $\begin{array}{l}\text { Lingkungan belajar mengajar sangat mendukung dan } \\
\text { meningkatkan pembelajaran Bahasa Inggris saya }\end{array}$ & $46 \%$ & $51 \%$ & $35 \%$ \\
\hline 9 & $\begin{array}{l}\text { Saya mengha-biskan lebih banyak waktu untuk me-ngerjakan } \\
\text { pekerjaan rumah Bahasa Inggris dari-pada mengerjakan peker- } \\
\text { jaan rumah dari orang lain }\end{array}$ & $8 \%$ & $21 \%$ & $17 \%$ \\
\hline 10 & $\begin{array}{l}\text { Saya bersedia untuk berpar-tisipasi dalam perkuliahan Bahasa } \\
\text { Inggris karena menantang }\end{array}$ & $33 \%$ & $58 \%$ & $60 \%$ \\
\hline 11 & $\begin{array}{l}\text { Saya puas dengan kemampuan Bahasa Inggris yang didapatkan } \\
\text { melalui perkuliahan }\end{array}$ & $26 \%$ & $15 \%$ & $17 \%$ \\
\hline
\end{tabular}


Dalam pendapat mereka mengenai lingkungan belajar mengajar, hampir setengah mahasiswa Sastra Jepang dan sebagian besar mahasiswa Ilmu Sejarah setuju hal itu sangat mendukung dan meningkatkan pembelajaran Bahasa Inggris mereka, namun belum merasa puas dengan kemampuan Bahasa Inggris yang didapatkan melalui perkuliahan. Sedangkan, mahasiswa Sastra Sunda merasa lingkungan belajar di kampus tidak mendukung, namun mereka merasa puas dengan apa yang mereka dapatkan dari perkuliahan Bahasa Inggris ini.

Secara ringkas, dapat disimpulkan bahwa Efektifitas perkuliahan Bahasa Inggris di Prodi Sastra Jepang belum dapat dicapai secara maksimal, mengingat walau mahasiswa senang belajar Bahasa Inggris, mampu memahami konsep Bahasa Inggris yang sulit dan merasa mampu mengerjakan tes-tesnya dengan baik, namun mereka merasa tidak puas dan berpendapat perkuliahan Bahasa Inggris yang mereka peroleh di semester satu kurang menantang dan tidak yakin apakah mereka dapat lebih jelas memahami materi karena peralatan audiovisual. Melihat dari hasil tes mereka, terlihat kemampuan memahami bacaan Bahasa Inggris mahasiswa prodi ini sangat baik, hingga sebenarnya mereka sudah siap menerima teks-teks dari level atas (advanced level), yang banyak terdapat dalam buku teks berbahasa Inggris dan jurnal ilmiah internasional.

Di kelas Prodi Ilmu Sejarah, efektifitas perkuliahan Bahasa Inggris dapat dicapai secara optimal, mengingat lingkungan belajar mengajar sangat mendukung dan meningkatkan pembelajaran Bahasa Inggris. Selain itu, mahasiswa senang belajar Bahasa Inggris dan menganggap belajar bahasa Inggris adalah hal yang menantang, walau masih merasa kesulitan dengan beberapa konsep dan tes-tesnya. Mahasiswa Prodi Ilmu Sejarah masih merasa belum puas dengan kemampuan yang didapatkan dari pembelajaran di program HITS 2016/2017. Bila melihat hasil tes Bahasa Inggris, kemampuan mereka dapat dikatakan sudah mencapai level menengah ke atas (upperintermediate) sehingga mereka cukup siap membaca buku teks berbahasa Inggris pada bidang ilmunya, walau perlu menambah banyak kosa-kata baru.

Di Prodi Sastra Sunda, efektifitas perkuliahan Bahasa Inggris di program HITS belum dicapai. Para mahasiswa merasa senang belajar Bahasa Inggris dan dapat memahami materi karena menggunakan peralatan audiovisual, serta menganggap pembelajaran bahasa Inggris di tahun ajaran 2016/2017 ini cukup menantang. Mereka juga merasa puas dengan kemampuan yang diperoleh dari perkuliahan ini. Namun, mereka berpendapat lingkungan belajar mengajar tidak terlalu mendukung dan tidak meningkatkan pembelajaran Bahasa Inggris mereka, serta masih merasa kesulitan untuk memahami beberapa konsep Bahasa Inggris dan belum yakin apakah dapat mengerjakan tes-tesnya. Melihat dari hasil tes mereka, kemampuan mahasiswa prodi ini dalam memahami bacaan berbahasa Inggris masih rendah, antara level dasar dan menengah (pre-intermediate). Oleh karena itu, dapat disimpukan bahwa pemberian materi pembelajaran mata kuliah Bahasa Inggris pada tahun ajaran 2016/2017 terlalu berat untuk mereka.

B. Model Perkuliahan Bahasa Inggris yang Diinginkan Mahasiswa

Poin kedua pada angket yng disebarkan adalah mengenai model perkuliahan. Hasil survey dapat dilihat pada tabel berikut:

\section{Tabel 5. Model Perkuliahan}

\begin{tabular}{|c|c|c|c|c|}
\hline \multirow{2}{*}{ No } & \multirow{2}{*}{ Pernyataan } & \multicolumn{3}{|c|}{ Jawaban } \\
\hline & & \multicolumn{3}{|c|}{ Sangat Setuju \& Setuju } \\
\hline \multicolumn{2}{|r|}{$\begin{array}{l}\text { B. Model Perkuliahan Bahasa } \\
\text { Inggris }\end{array}$} & $\begin{array}{c}\text { Sastra } \\
\text { Jepang }\end{array}$ & $\begin{array}{c}\text { Ilmu } \\
\text { Sejarah }\end{array}$ & $\begin{array}{l}\text { Sastra } \\
\text { Sunda }\end{array}$ \\
\hline 1 & $\begin{array}{l}\text { Metode pengajaran } \\
\text { yang berpusat pada } \\
\text { mahasiswa memberi } \\
\text { lebih banyak kebebasan } \\
\text { untuk mengeksplorasi } \\
\text { kemampuan Bahasa } \\
\text { Inggris saya }\end{array}$ & $54 \%$ & $47 \%$ & $62 \%$ \\
\hline 2 & $\begin{array}{l}\text { Untuk mengembangkan } \\
\text { kemampuan berbicara } \\
\text { Bahasa Inggris maka } \\
\text { mahasiswa perlu diberikan } \\
\text { kesempatan role play } \\
\text { atau presentasi dalam } \\
\text { perkuliahan }\end{array}$ & $74 \%$ & $75 \%$ & $83 \%$ \\
\hline 3 & $\begin{array}{l}\text { Dalam perkuliahan Bahasa } \\
\text { Inggris, saya pikir amat } \\
\text { penting untuk belajar } \\
\text { memecahkan masalah }\end{array}$ & $74 \%$ & $70 \%$ & $88 \%$ \\
\hline 4 & $\begin{array}{l}\text { Dalam perkuliahan } \\
\text { Bahasa Inggris, saya } \\
\text { pikir amat penting untuk } \\
\text { berpartisipasi dalam } \\
\text { aktivitas inkuiri (penemuan } \\
\text { konsep secara mandiri) }\end{array}$ & $62 \%$ & $58 \%$ & $67 \%$ \\
\hline 5 & $\begin{array}{l}\text { Saya bersedia untuk } \\
\text { berpartisipasi dalam } \\
\text { perkuliahan Bahasa } \\
\text { Inggris apabila dosen } \\
\text { menggunakan berbagai } \\
\text { metode pem belajaran }\end{array}$ & $77 \%$ & $85 \%$ & $83 \%$ \\
\hline 6 & $\begin{array}{l}\text { Saya bersedia untuk } \\
\text { berpartisipasi dalam } \\
\text { perkuliahan Bahasa } \\
\text { Inggris apabila mahasiswa } \\
\text { dilibatkan dalam diskusi }\end{array}$ & $64 \%$ & $85 \%$ & $79 \%$ \\
\hline 7 & $\begin{array}{l}\text { Saya menikmati nyanyian } \\
\text { nyanyian bahasa Inggris } \\
\text { di kelas }\end{array}$ & $90 \%$ & $85 \%$ & $87 \%$ \\
\hline 8 & $\begin{array}{l}\text { Saya menikmati permainan } \\
\text { dan tugas dalam bahasa } \\
\text { Inggris di kelas }\end{array}$ & $77 \%$ & $75 \%$ & $69 \%$ \\
\hline 9 & $\begin{array}{l}\text { Saya menikmati komuni- } \\
\text { kasi dosen dan mahasiswa } \\
\text { dalam Bahasa Inggris } \\
\text { selama perkuliahan }\end{array}$ & $49 \%$ & $53 \%$ & $33 \%$ \\
\hline 10 & $\begin{array}{l}\text { Saya senang diberikan } \\
\text { kesempatan berkomunikasi } \\
\text { dalam Bahasa Inggris } \\
\text { dengan mahasiswa lain } \\
\text { selama per-kuliahan }\end{array}$ & $62 \%$ & $64 \%$ & $54 \%$ \\
\hline 11 & $\begin{array}{l}\text { Saya lebih tertarik } \\
\text { apabila Bahasa Inggris } \\
\text { diajarkan dengan } \\
\text { kreativitas }\end{array}$ & $90 \%$ & $96 \%$ & $87 \%$ \\
\hline
\end{tabular}




\begin{tabular}{|c|c|c|c|c|}
\hline 12 & $\begin{array}{l}\text { Metode perkuliahan } \\
\text { yang menyenangkan } \\
\text { adalah ketika dosen } \\
\text { memberikan perkuliahan } \\
\text { melalui ceramah }\end{array}$ & $13 \%$ & $17 \%$ & $21 \%$ \\
\hline 13 & $\begin{array}{l}\text { Dosen perlu } \\
\text { mendatangkan native } \\
\text { speaker minimal sekali } \\
\text { dalam perkuliahan } \\
\text { Bahasa Inggris }\end{array}$ & $90 \%$ & $91 \%$ & $81 \%$ \\
\hline
\end{tabular}

Sebagian besar mahasiswa dari tiga prodi ini menilai bahwa pengajaran yang berpusat pada mahasiswa memberi lebih banyak kebebasan untuk mengeksplorasi kemampuan Bahasa Inggris, juga menilai bahwa untuk mengembangkan kemampuan berbicara Bahasa Inggris perlu menggunakan metode pembelajaran yang variatif: presentasidandiskusi/bermain peran/permainan/menonton film/ penemuan konsep secara mandiri/pemecahan masalah sendiri/ mendengarkan lagu, dan sebagian besar dari mereka tidak menyukai metode ceramah. Hampir setengah dari mahasiswa Sastra Jepang dan Ilmu Sejarah menikmati komunikasi dosen dan mahasiswa, juga antar mahasiswa, dalam Bahasa Inggris selama perkuliahan, namun mahasiswa Sastra Sunda ragu apakah mereka dapat melakukan komunikasi dalam Bahasa Inggris dengan dosen. Hampir seluruh mahasiswa dari tiga prodi ini menilai bahwa dosen perlu mendatangkan penutur asli minimal sekali dalam perkuliahan Bahasa Inggris.

\section{Kebutuhan Konten dan Keterampilan Bahasa Inggris}

Tabel berikut menunjukkan hasil survey pada poin ketiga.

Tabel 6. Kebutuhan Konten dan Keterampilan

\begin{tabular}{|c|c|c|c|c|}
\hline \multirow{2}{*}{ No } & \multirow{2}{*}{ Pernyataan } & \multicolumn{3}{|c|}{ Jawaban } \\
\hline & & \multicolumn{3}{|c|}{ Sangat Setuju \& Setuju } \\
\hline & $\begin{array}{l}\text { Kebutuhan Konten dan Kete- } \\
\text { rampilan Bahasa Inggris }\end{array}$ & $\begin{array}{l}\text { Sastra } \\
\text { Jepang }\end{array}$ & $\begin{array}{c}\text { Ilmu } \\
\text { Sejarah }\end{array}$ & $\begin{array}{l}\text { Sastra } \\
\text { Sunda }\end{array}$ \\
\hline 1 & $\begin{array}{l}\text { Saya menyadari bahwa } \\
\text { kemampuan berbahasa Inggris } \\
\text { sangat penting mengingat } \\
\text { peluang kerja }\end{array}$ & $100 \%$ & $98 \%$ & $98 \%$ \\
\hline 2 & $\begin{array}{l}\text { Saya terdorong untuk } \\
\text { membaca majalah dan surat } \\
\text { kabar Inggris, dengarkan berita } \\
\text { Inggris dan program menonton } \\
\text { dalam bahasa Inggris. }\end{array}$ & $92 \%$ & $68 \%$ & $63 \%$ \\
\hline 3 & $\begin{array}{l}\text { Belajar Bahasa Inggris } \\
\text { penting karena saya } \\
\text { menggunakannya dalam } \\
\text { kehidupan sehari-hari }\end{array}$ & $56 \%$ & $53 \%$ & $48 \%$ \\
\hline 4 & $\begin{array}{l}\text { Saya pikir belajar bahasa } \\
\text { Inggris membantu saya untuk } \\
\text { belajar bahasa asing lainnya. }\end{array}$ & $87 \%$ & $87 \%$ & $81 \%$ \\
\hline 5 & $\begin{array}{l}\text { Dalam perkuliahan bahasa } \\
\text { Inggris saya lebih senang } \\
\text { apabila Dosen menekankan } \\
\text { empat keterampilan bahasa } \\
\text { (mendengarkan, berbicara, } \\
\text { membaca dan menulis) }\end{array}$ & $87 \%$ & $92 \%$ & $90 \%$ \\
\hline 6 & $\begin{array}{l}\text { Saya lebih tertarik mengikuti } \\
\text { perkuliahan Bahasa Inggris } \\
\text { apabila dosen menekankan } \\
\text { pada kemampuan berbicara }\end{array}$ & $69 \%$ & $77 \%$ & $67 \%$ \\
\hline 7 & $\begin{array}{l}\text { Saya lebih tertarik mengikuti } \\
\text { perkuliahan Bahasa Inggris } \\
\text { apabila dosen menekankan }\end{array}$ & $67 \%$ & $60 \%$ & $60 \%$ \\
\hline
\end{tabular}

8 Melalui perkuliahan Bahasa Inggris, saya ingin bisa memahami film dan program $\quad 90 \% \quad 85 \% \quad 81 \%$ TV Inggris tanpa melihat subtitel

9 Melalui perkuliahan Bahasa Inggris, saya ingin belajar tentang gaya hidup dan kebiasaan di mancanegara seperti Inggris dan Amerika

10 Saya ingin bisa mengucapkan bahasa Inggris seperti orang $\quad 74 \% \quad 87 \% \quad 85 \%$ Inggris atau Amerika

Berkaitan dengan konten materi dari pembelajaran Bahasa Inggris, hampir semua mahasiswa tiga prodi ini beranggapan bahwa dalam perkuliahan bahasa Inggris, mereka senang apabila dosen menekankan empat keterampilan bahasa (mendengarkan, berbicara, membaca dan menulis). Hampir semua juga menilai bahwa melalui perkuliahan Bahasa Inggris, ingin bisa memahami film dan program TV Inggris tanpa melihat subtitel dan sebagian besar mereka ingin belajar tentang gaya hidup dan kebiasaan di mancanegara seperti Inggris dan Amerika. Sebagian besar mahasiswa baik dari Sastra Jepang, Ilmu Sejarah, maupun Sastra Sunda ingin bisa mengucapkan bahasa Inggris seperti orang Inggris atau Amerika.

\section{Perkuliahan Bahasa Inggris Lanjutan}

Hasil dari survey pada poin ini dapat diliha pada tabel berikut.

Tabel 7. Perkuliahan Lanjutan

\begin{tabular}{|c|c|c|c|c|}
\hline \multirow{2}{*}{ No } & \multirow{2}{*}{ Pernyataan } & \multicolumn{3}{|c|}{ Jawaban } \\
\hline & & \multicolumn{3}{|c|}{ Sangat Setuju \& Setuju } \\
\hline D. & $\begin{array}{l}\text { Perkuliahan Bahasa Inggris } \\
\text { Lanjutan }\end{array}$ & $\begin{array}{l}\text { Sastra } \\
\text { Jepang }\end{array}$ & $\begin{array}{c}\text { Ilmu } \\
\text { Sejarah }\end{array}$ & $\begin{array}{l}\text { Sastra } \\
\text { Sunda }\end{array}$ \\
\hline 1 & $\begin{array}{l}\text { Saya ingin ada mata kuliah } \\
\text { Bahasa Inggris lanjutan } \\
\text { agar dapat berteman dengan } \\
\text { orang-orang yang tinggal di } \\
\text { luar negeri dengan bertukar } \\
\text { surat dan e-mail }\end{array}$ & $59 \%$ & $79 \%$ & $69 \%$ \\
\hline 2 & $\begin{array}{l}\text { Menurut saya perlu ada } \\
\text { perkuliahan Bahasa Inggris } \\
\text { yang khusus mempersiapkan } \\
\text { kemampuan untuk } \\
\text { meningkatkan nilai TOEFL } \\
\text { atau IELTS }\end{array}$ & $95 \%$ & $83 \%$ & $98 \%$ \\
\hline 3 & $\begin{array}{l}\text { Saya ingin ada mata kuliah } \\
\text { khusus Bahasa Inggris yang } \\
\text { membekali kemampuan } \\
\text { membaca buku dan jurnal } \\
\text { berbahasa Inggris dengan } \\
\text { mudah }\end{array}$ & $74 \%$ & $89 \%$ & $88 \%$ \\
\hline 4 & $\begin{array}{l}\text { Menjelang akhir } \\
\text { perkuliahan, saya ingin } \\
\text { mendapatkan bekal Bahasa } \\
\text { Inggris yang menunjang } \\
\text { dunia kerja }\end{array}$ & $95 \%$ & $92 \%$ & $100 \%$ \\
\hline
\end{tabular}

Pada poin ini juga, mahasiswa dari tiga prodi ini menyadari bahwa kemampuan berbahasa Inggris sangat penting mengingat peluang kerja dan hampir semuanya terdorong untuk membaca majalah dan surat kabar Inggris, pada kemampuan menulis 
mendengarkan berita Inggris dan program menonton dalam bahasa Inggris. Sebagian besar mahsiswa Sastra Jepang dan Ilmu Sejarah menilai bahwa bahasa Inggris penting karena mereka dapat menggunakannya dalam kehidupan sehari-hari, namun kurang dari setengah mahasiswa Sastra Sunda yang menyetujui hal tersebut. Hampir semua dari mahasiswa ditiga prodi ini berpendapat bahwa belajar bahasa Inggris membantunya untuk belajar bahasa asing lainnya.

Tentang perlu tidaknya perkuliahan Bahasa Inggris Lanjutan, sebagian besar mahasiswa ingin ada mata kuliah Bahasa Inggris lanjutan agar dapat berteman dengan orang-orang yang tinggal di luar negeri dengan bertukar surat dan e-mail, dan dapat membaca buku dan jurnal berbahasa Inggris dengan mudah. Hampir semua juga menilai bahwa perlu ada perkuliahan Bahasa Inggris yang khusus mempersiapkan kemampuan untuk meningkatkan nilai TOEFL atau IELTS, dan yang memberikan bekal Bahasa Inggris yang menunjang dunia kerja.

\section{SIMPULAN}

Dari penelitian terhadap tiga prodi di Fakultas Ilmu Budaya Universitas Padjadjaran dapat terlihat tiga hal penting terkait dengan efektifitas pembelajaran Bahasa Inggris di program HITS 2016/2017. Mahasiswa Prodi Sastra Jepang mempunyai kemampuan memahami bacaan Bahasa Inggris dengan sangat baik terlihat dari rata-rata jawaban betul pada semua jenis pertanyaan dalam tes, yaitu di atas $80 \%$. Namun, hampir setengah dari mereka tidak puas dan belum merasa tertantang dengan model pembelajarannya.

Mahasiswa Prodi Ilmu Sejarah dapat mengikuti pembelajaran Bahasa Inggris dengan cukup baik dengan melihat rata-rata jawaban betul untuk empat jenis pertanyaan dalam tes di atas $60 \%$, dan hanya satu yang di bawahnya. Namun, sebagian besar dari mereka belum merasa puas dengan model pembelajarannya karena masih merasa kesulitan dalam memahami beberapa konsep dan dalam mengerjakan tes-tesnya. Mahasiswa Prodi Sastra Sunda masih harus banyak berlatih untuk memahami teks Bahasa Inggris karena rata-rata jawaban betul pada empat jenis pertanyaan dalam tes di bawah $60 \%$, hanya satu yang berada di atasnya. Namun, mereka sudah merasa puas dengan pembelajarannya: materinya cukup menarik dan variatif, serta metodenya menantang.

\section{UCAPAN TERIMAKASIH}

Tim peneliti mengucapkan terimakasih pada Universitas Padjadjaran, Bandung, atas bantuan dana yang diberikan melalui Hibah Internal Unpad (HIU) tahun 2017.

\section{DAFTAR PUSTAKA}

Adtyarini, H., Wijayanto, A. \& Masykuroh, Q. (2009). Sikap Mahasiswa Program Studi Bahasa Inggris Universitas Muhammadiyah Surakarta terhadap
Variasi Bahasa Inggris. Jurnal Penelitian Humaniora UNY, 10, (1), 71-80.

Aziz, M.S.A. (1994). Attitudes towards English: A Survey of UKM Undergraduates. Jurnal Akademika Universiti Kebangsaan Malaysia, 44, (1), 85-99.

Boone, H.N. \& Boone, D.A. (2012). Analyzing Likert Data. Journal of Extension, West Virginia University, 50, (2), 1-5

Grabe, W.F.S. (2011). Teaching and Researching Reading. New York: Longman.

Kintsch, W. (1998). Comprehension: A Framework for Cognition. New York: Cambridge University Press.

Kintsch, W. \& van Dijk, T.A. (1978). Toward a Model of Discourse Comprehension and Production. Jurnal Psychological Review, 85, (5), 363-394.

Kusuma, I., \& Adnyani, S. (2016). Motivasi dan Sikap Bahasa Mahasiswa Jurusan Pendidikan Bahasa Inggris Undiksha. Jurnal Pendidikan Indonesia, 5, (1), 702-713.

Manggong, L., Sachmadi, I.F. \& Indrayani, L.M. (2017). Sikap terhadap Bahasa Ingris: Survey terhadap Mahasiswa Universitas Padjadjaran Kampus Pangandaran. Jurnal Pengabdian Kepada Masyarakat, 1, (5), 317-321.

Manurung, R. T. (2011). Pengajaran Bahasa yang Berkarakter Kebangsaan dan Berspektif Multibudaya dalam Era Globalisasi. Sosiohumaniora, 13, (2), 235-242.

Muflihah. (2016). Tingkat Kemampuan Membaca Teks Bahasa Inggris: Studi Kasus Mahasiswa Kelas Bilingual IAIN Purwokerto. Yogyakarta: Paper presented at the Consorsium of Linguistics and Literature: Contemporary Issues in English Linguistics, Literature, and Educations.

Pratiwi, V.U., Astuti, P.I. \& Handayani. S. (2015). Kemampuan Membaca Teks Bahasa Inggris. Magister Scientiae, 38, (1), 132-142.

Rohman, A.S., \& Prijana. (2016). Kemampuan Baca Mahasiswa pada Buku Teks. Sosiohumaniora, Unpad, 18, (3), 255-260.

Siregar, A.T., \& Evangline, H. (2017). Kemampuan Berbahasa Inggris, Motivsai dan Sikap terhadap Bahasa Inggris Mahasiswa Program Studi Ilmu Keperawatan (S1) STIKES Jenderal Achmad Yani Cimahi. Skolastik Keperawatan, 3, (1), 1118.

Tantra, D.K., Mahayanti, N.W.S. \& Ratminingsih, N.M. (2014). Pengaruh Motivasi Belajar dan Sikap 
Bahasa terhadap Prestasi Belajar Keterampilan Berbahasa Mahasiswa Jurusan Pendidikan Bahasa Inggris. Paper presented at the Seminar Nasional Riset Inovatif
Wiji. (2014). Pengembangan Desain Perkuliahan Kimia Sekolah Berbasis Model Mental untuk Meningkatkan Pemahaman Materi Subyek Mahasiswa Calon Guru Kimia. (Doctoral Degree), Universitas Pendidikan Indonesia. 